\title{
ДОСЛІДЖЕННЯ ПАРАМЕТРІВ ЕКСТРАКЦІї ТРАВИ ПРИВОРОТНЯ
}

\section{RESEARCH OF EXTRACTION PARAMETERS OF ALCHEMILLA SUBCRENATA BUS. HERB}

Андрій Грицик (Andrii Grytsyk) ${ }^{1}$, Наталія Дубель (Nataliia Dubel) ${ }^{1}$, Любов Грицик (Lyubov Grytsyk) ${ }^{1}$

1 Івано-Франківський національний медичний університет, Івано-Франківськ, Україна (IvanoFrankivsk National Medical University, IvanoFrankivsk, Ukraine)

${ }^{*}$ Corresponding author: Nataliia Dubel, affiliated to IvanoFrankivsk National Medical University, Ivano-Frankivsk, Ukraine
Received: November 02, 2021

Published: November 12, 2021
Abstract. The technological parameters of Alchemilla subcrenata Bus. herb were studied. During the research, authors have determined the following: weight loss during drying, specific, volume and bulk density, porosity and free volume of the medicinal plant raw materials. The optimal conditions for obtaining extracts of the investigated raw material (particle size, raw material-extractant ratio, infusion time, extraction frequency) were experimentally established.

Keywords: technological parameters, medicinal plant raw materials, Alchemilla subcrenata Bus.

Вступ. Розробка технології виготовлення фітопрепаратів вимагає індивідуального підходу до вивчення технологічних властивостей лікарської рослинної сировини (ЛРС), яку використовують при їх виробництві. Адже технологічні параметри ЛРС $\epsilon$ вирішальними чинниками в досягненні терапевтичного ефекту фітозасобу. Це стосується виду ЛРС, вибору методу екстрагування, ступеня подрібнення сировини, розчинника, співвідношення сировина - екстрагент, часу екстрагування та кратності екстракції [1 - 3].

При розробці фітопрепаратів основним завданням $\epsilon$ забезпечення максимального виходу діючих речовин. Успішне вирішення цього завдання залежить від того, наскільки будуть враховані всі фактори, що впливають на ефективність процесу екстракції [2, 3].

Мета. Визначення технологічних параметрів трави приворотня (п.) зарубчастого та вибір оптимальних умов екстрагування для одержання екстрактів з досліджуваної рослинної сировини.

Об'єктом дослідження обрано траву п. зарубчастого, заготовлену в околицях смт. Ворохта Івано-Франківської області у 2020 р.

Приворотень зарубчастий (A. subcrenata Bus.) - багаторічна трав'яниста рослина родини Розові, що вміщує таніни, флавоноїди, гідроксикоричні кислоти, кумарини, мікроелементи, вітаміни та ін. [4].

Матеріали та методи дослідження. Для підвищення ефективності процесу екстрагування та визначення витратних норм ЛРС та екстрагенту на 
першому етапі роботи нами проведено визначення основних технологічних параметрів трави п. зарубчастого за загальноприйнятими методиками $[2,5]$.

Визначення втрати в масі при висушуванні ЛРС проводили за методикою ДФУ 2.0 [5] і обчислювали за формулою (1):

$$
X=\frac{\left(m-m_{1}\right) \cdot 100}{m},
$$

де $\mathrm{m}$ - маса сировини до висушування, в грамах;

$\mathrm{m}_{1}$ - маса сировини після висушування, в грамах.

Питому густину визначали як відношення маси абсолютно сухої подрібненої сировини до об’єму рослинної сировини [5]. Розрахунок питомої густини ЛРС проводили за формулою (2):

$$
d_{n}=\frac{P \cdot d_{\varkappa}}{P+G-F}
$$

де $\mathrm{P}$ - вага абсолютно сухої подрібненої сировини, в грамах;

$\mathrm{G}$ - вага пікнометра з водою, в грамах;

F - вага пікнометра з водою і сировиною, в грамах;

$\mathrm{d}_{\text {ж }}$ - питома вага води, в грамах на сантиметр кубічний $\left(\mathrm{d}_{\text {ж }}=0,9982\right.$ г/ $\left.\mathrm{cm}^{3}\right)$.

Об 'ємну густину визначали як співвідношення маси подрібненої сировини при природній або заданій вологості до іï повного об’єму, що вміщує пори, тріщини і капіляри, заповнені повітрям (Формула 3).

$$
d_{o}=\frac{P_{o}}{V_{o}}
$$

де $\mathrm{P}_{\mathrm{o}}$ - вага подрібненої сировини при природній або заданій вологості, в грамах;

$\mathrm{V}_{\mathrm{o}}$ - об'єм, який займає сировина, в сантиметрах кубічних.

Насипну густину визначали як відношення подрібненої сировини при природній або заданій вологості до повного об'єму, що займає сировина разом 3 порами часток та вільним об’ємом між ними [5]. Розрахунок насипної густини ЛРС проводили за формулою (4):

$$
d_{H}=\frac{P_{H}}{V_{H}},
$$

де $\mathrm{P}_{\mathrm{H}}$ - вага подрібненої сировини при природній або заданій вологості, в г;

$\mathrm{V}_{\text {н }}$ - об'єм, який займає сировина, в см³.

За результатами визначення питомої, об’ємної та насипної густини були проведені розрахунки пористості, порізності та вільного об’єму шару сировини.

Пористість сировини характеризували як величину порожнин всередині частинок сировини і визначали як відношення різниці між питомою і об'ємною густиною до питомої густини (Формула 5).

$$
\Pi_{c}=\frac{d_{n}-d_{o}}{d_{n}},
$$

де $\mathrm{d}_{\text {п }}-$ питома густина сировини, в грамах на сантиметр кубічний;

$\mathrm{d}_{\mathrm{o}}$ - об’ємна густина сировини, в грамах на сантиметр кубічний. 
Порізність шару характеризували як величину порожнин між частинками рослинного матеріалу і визначали як відношення різниці між об’ємною і насипною густиною до об’ємної густини (Формула 6).

$$
\Pi_{u}=\frac{d_{o}-d_{H}}{d_{o}}
$$

де $\mathrm{d}_{\mathrm{o}}$ - об'ємна густина сировини, в грамах на сантиметр кубічний;

$\mathrm{d}_{\mathrm{H}}-$ насипна густина сировини, в грамах на сантиметр кубічний.

Вільний об'єм шару характеризували як відносний об'єм вільного простору в одиниці шару сировини (порожнини всередині частинок і між ними). Його розраховували як відношення різниці між питомою і насипною густиною до питомої густини (Формула 7).

$$
V=\frac{d_{n}-d_{H}}{d_{n}},
$$

де $\mathrm{d}_{\text {п }}$ - питома густина сировини, в грамах на сантиметр кубічний;

$\mathrm{d}_{\mathrm{H}}-$ насипна густина сировини, в грамах на сантиметр кубічний.

Визначені технологічні параметри трави п. зарубчастого використано для опрацювання оптимальних умов екстракції досліджуваної сировини.

Одним із основних факторів, що інтенсифікує процес екстрагування біологічно активних речовин (БАР) з ЛРС є ступінь подрібнення, який впливає як на густину, коефіцієнти поглинання і набухання ЛРС, так і на швидкість дифузії та повноту витягання екстрактивних речовин $[1,2]$. Ступінь подрібнення сировини оцінювали за допомогою ситового аналізу [5].

Висушену траву п. зарубчастого подрібнювали на млинку типу “Ексцельсіор" і просіювали крізь сита 3 діаметром отворів 0,2; 0,5; 1,0; 2,5; 3,0; 4,5; 5,5; 7,0 мм. 3 кожної фракції відбирали точну наважку сировини та екстрагували водою очищеною $P$ у співвідношенні сировини до екстрагенту 1:50 при температурі $80-90^{\circ} \mathrm{C}$ протягом 30 хв при періодичному перемішуванні. Витяжку охолоджували, фільтрували, при необхідності доводили водою до початкового об'єму. Ефективність екстракції оцінювали за сумарним вмістом екстрактивних речовин та окиснюваних фенолів.

При виборі екстрагента враховували хімічний склад трави приворотня, який представлений, в основному, фенольними речовинами та полісахаридами, які мають добру розчинність у воді та етанолі певної концентрації. Тому, як можливі екстрагенти, було використано воду і водно-спиртові суміші з різним вмістом етанолу $P(20 \%, 40 \%, 70 \%, 90 \%, 96 \%)$.

Враховуючи оптимальний ступінь подрібнення трави приворотня одержували витяжки за описаною вище методикою різними розчинниками за однакових умов.

Для встановлення оптимального часу екстракції БАР проводили екстрагування із трави п. зарубчастого водою очищеною $P, 40$ \% і 70 \% етанолом $P$, у співвідношенні сировина-екстрагент 1:50 протягом 15 хв, 30 хв, 45 хв та 60 хв на водяному нагрівнику при періодичному перемішуванні. 
Для встановлення оптимального співвідношення між сировиною i екстрагентами, яке має важливий вплив на перехід БАР у витяжку, нами були використані співвідношення 1:5; 1:10; 1:15; 1:20; 1:50.

Для встановлення кратності екстракцій трави п. зарубчастого нами були виготовлені, при раніше вибраних оптимальних умовах, водні і водно-спиртові витяжки після одно- та п’ятикратної екстракції.

Результати дослідження та їх обговорення. Результати визначення основних технологічних параметрів трави п. зарубчастого наведено у таблиці 1.

Таблиця 1. Основні технологічні параметри трави приворотня зарубчастого.

\begin{tabular}{|l|c|c|}
\hline Назва технологічного параметра & $\begin{array}{c}\text { Одиниці } \\
\text { вимірювання }\end{array}$ & $\begin{array}{c}\text { Результати визначень } \\
\mathrm{n}=5\end{array}$ \\
\hline Втрата в масі при висушуванні & $\%$ & $8,40 \pm 0,53$ \\
\hline Питома густина & $\Gamma / \mathrm{cm}^{3}$ & $1,1850 \pm 0,0053$ \\
\hline Об’ємна густина & $\Gamma / \mathrm{cm}^{3}$ & $0,4948 \pm 0,0131$ \\
\hline Насипна густина & $\Gamma / \mathrm{cm}^{3}$ & $0,0741 \pm 0,0017$ \\
\hline Пористість шару сировини & - & 0,5824 \\
\hline Порізність шару сировини & - & 0,8502 \\
\hline Вільний об'єм шару сировини & - & 0,9375 \\
\hline
\end{tabular}

За результатами визначення технологічних параметрів трави п. зарубчастого (Табл. 1) встановлено, що втрата в масі при висушуванні становила

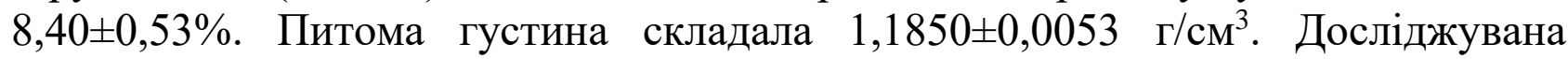
сировина характеризувалася невеликою об'ємною густиною та низькою насипною густиною $\left(0,4948 \pm 0,0131 \mathrm{r} / \mathrm{cm}^{3}\right.$ та $0,0741 \pm 0,0017 \mathrm{\Gamma} / \mathrm{cm}^{3}$ відповідно). Досить високі значення мали такі показники як пористість, порізність та вільний об'єм шару сировини $(0,5824,0,8502$ та 0,9375 відповідно), що вказувало на добру поглинаючу здатність сировини.

Отримані результати дозволяють встановити оптимальні параметри процесу екстрагування: обрати обладнання для змішування та екстрагування; визначити потенційну пропускну здатність шару сировини; визначити об'єм, який займає суха і набухла сировина.

Результати дослідження впливу ступеня подрібнення трави приворотня на повноту екстракції БАР наведено на рис. 1 .

За результатами визначення оптимальних умов екстрагування (Рис. 1) встановлено, що максимальне вивільнення екстрактивних речовин та окиснюваних фенолів відбувалося при подрібненні трави п. зарубчастого до частинок, розміром 0,5-2,5 мм (сумарно 20,81\% та 7,32\% відповідно). Подрібнення до розміру частинок менше 0,5 мм та більше 7,0 мм призводило до зниження виходу діючих речовин. Таким чином, експериментально підтверджено, що оптимальним ступенем подрібнення для трави п. зарубчастого був розмір частинок від 0,5 до 2,5 мм. 


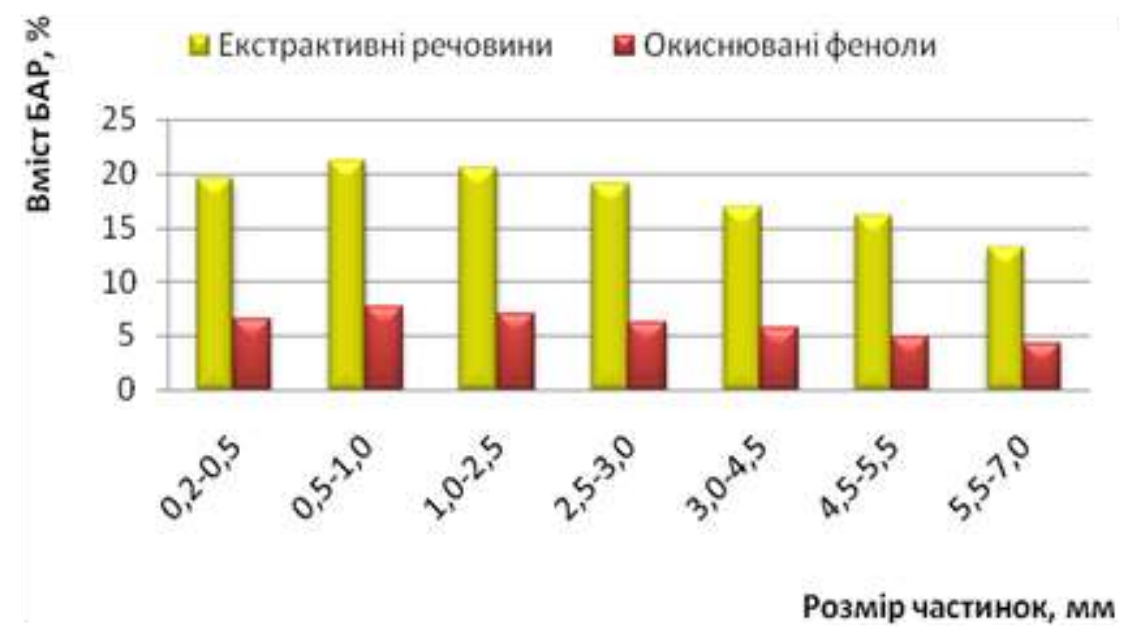

Рис. 1. Залежність повноти екстракції БАР від ступеня подрібнення трави приворотня зарубчастого.

Результати кількісного вмісту екстрактивних речовин і окиснюваних фенолів у витяжках при виборі екстрагенту наведено на рис. 2.

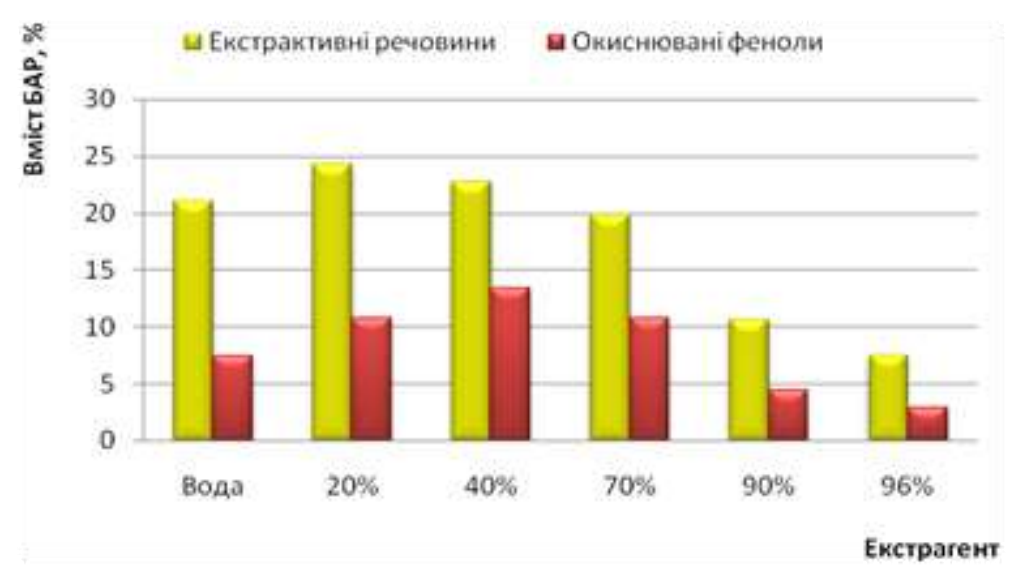

Рис. 2. Вплив природи екстрагенту на повноту екстракції БАР із трави приворотня зарубчастого.

Отримані експериментальні дані, представлені на рис. 2, свідчать, що за здатністю екстрагувати окиснювані феноли з трави п. зарубчастого значну перевагу мав $40 \%$ спирт етиловий $P$, який забезпечував максимальний вихід вказаних сполук $-13,4 \%$. Вихід екстрактивних речовин при цьому становив $22,69 \%$. При екстрагуванні трави п. зарубчастого 20\% спиртом етиловим $P$ спостерігали найбільний вихід екстрактивних речовин $(24,21 \%)$ та зменшення виходу окиснюваних фенолів на $2,67 \%$ в порівнянні з $40 \%$ етанолом $(10,73 \%)$. Дещо меншим вмістом БАР характеризувалась витяжка, екстрагована 70\% спиртом етиловим $P$, вихід екстрактивних речовин якої становив 19,81\%, а окиснюваних фенолів - 10,78\%. Подальше збільшення концентрації етанолу призводило до зменшення ступеня вилучення БАР, що, в свою чергу, обумовлено присутністю в ЛРС таких спирторозчинних сполук, як хлорофіли та каротиноїди. 
Тому, застосування 90\% та 96\% спирту етилового $P$ як екстрагенту було недоцільним. При використанні води очищеної $P$ як екстрагенту, масова частка окиснюваних фенолів у траві п. зарубчастого становила 7,48\%, а екстрактивних речовин $-21,1 \%$. У порівнянні з $40 \%$ етанолом $P$, вихід окиснюваних фенолів зменшувався на $5,92 \%$, а вміст екстрактивних речовин - лише на $1,68 \%$, що обумовлено поганою розчинністю фенольних сполук у воді.

Оскільки $20 \%$ етанол $P$ - це спирт низької концентрації, у який погано переходить комплекс фенольних сполук, тому оптимальними екстрагентами обрано $40 \%$ i $70 \%$ етанол $P$. Також для подальших досліджень у якості екстрагента відібрано воду очищену $P$ як найбільш універсальний та економічно доступний розчинник. Такий підхід дозволить одержати екстракти 3 достатньо високим вмістом БАР.

Результати залежності вмісту БАР в одержаних витяжках від часу екстракції наведено на рис. 3.
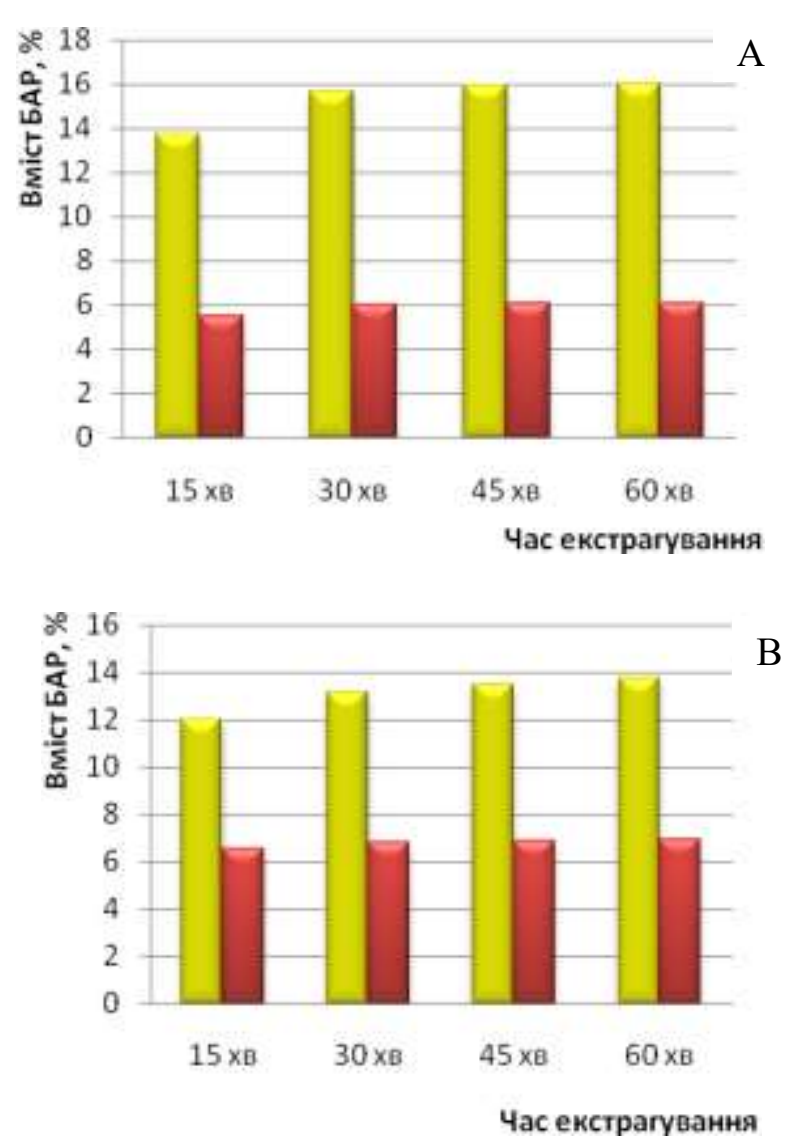

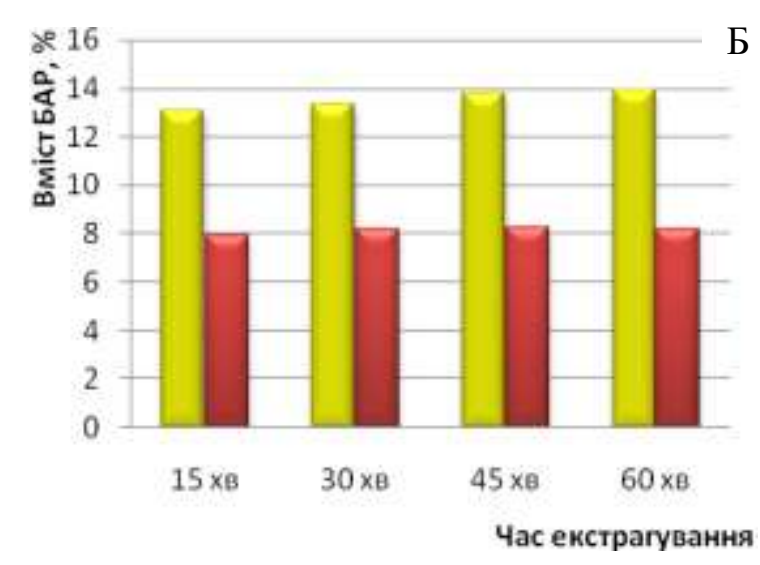

А - вода очлщена ш Екстрактивні речовини
Б - $40 \%$ етанол
В - $70 \%$ етанол шокиснюваніфеноли

Рис. 3. Вплив часу екстракції на вихід БАР із трави приворотня зарубчастого.

Результати дослідження (Рис. 3) показали, що повнота виділення БАР 3 сировини п. зарубчастого досягалася при екстракції протягом 30 хв, подальше збільшення часу екстрагування суттєво не впливало на вивільнення БАР. Даний часовий режим забезпечував вихід $15,64 \%, 13,31 \%$ та $13,15 \%$ екстрактивних речовин для витяжок, екстрагентами яких були вода очищена $P, 40 \%$ та 70\% 
етанол $P$ відповідно. Вивільнення окиснюваних фенолів за цей час становило $6,02 \%, 8,17 \%$ та 6,79\% відповідно.

Результати вибору оптимального співвідношення між ЛРС і екстрагентами наведено на рис. 4.
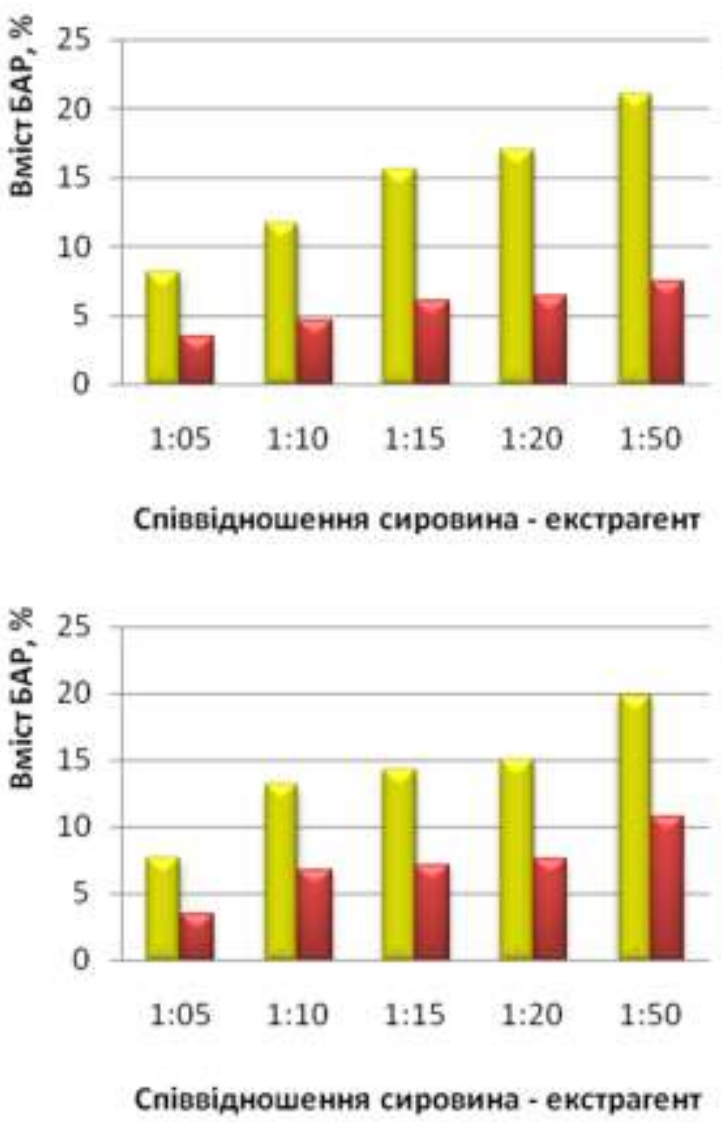

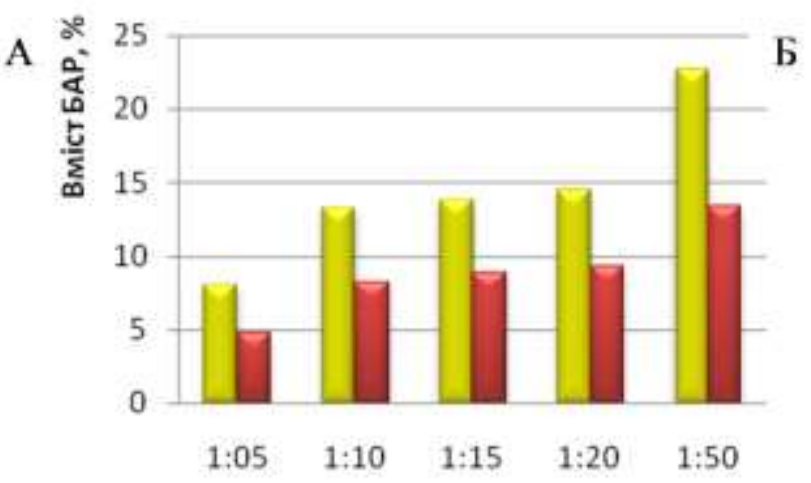

Співвідношення сировина - екстрагент

B

$$
\begin{aligned}
& \text { А - вода очшщена } \\
& \text { Б - } 40 \% \text { еканол } \\
& \text { В - } 70 \% \text { етанолтині речовини }
\end{aligned}
$$

Рис. 4. Вибір оптимального співвідношення між рослинною сировиною i екстрагентом.

В результаті проведених досліджень (Рис. 4) встановлено, що найвищий вихід БАР спостерігали при співвідношенні сировини і екстрагента 1:50. Проте, для екстрагування комплексу БАР трави п. зарубчастого велике значення має як високий вихід БАР, так і збереження високих концентрацій діючих речовин у витяжках, оскільки одержані екстракти в подальшому будуть використані для розробки лікарської форми. Тому оптимальними співвідношеннями між сировиною і екстрагентами для трави п. зарубчастого обрано 1:15 (вода очищена $P$ ) і 1:10 (екстрагент 40\% та 70\% етанол $P$ ), які дозволяють одержувати достатньо концентровані витяжки з високим виходом БАР. Подальше збільшення об'єму водної та спирто-водневої фази по відношенню до трави п. зарубчастого, приводило до незначного зросту БАР.

Результати вибору оптимальної кратності екстракцій наведено на рис. 5.

Згідно проведених досліджень (Рис. 5) встановлено, що повнота вилучення БАР $з$ трави п. зарубчастого найбільш активно проходила при чотирикратній екстракції витяжки. Потім активність екстрагування не зростала. Сумарний 
вихід екстрактивних речовин при чотирикратній екстракції для води очищеної, $40 \%$ та $70 \%$ спирту етилового складав $31,26 \%, 26,43 \%$ та 26,87\% відповідно; сумарний вихід окиснюваних фенолів - 10,53\%, 17,32\% та 15,39\% відповідно.
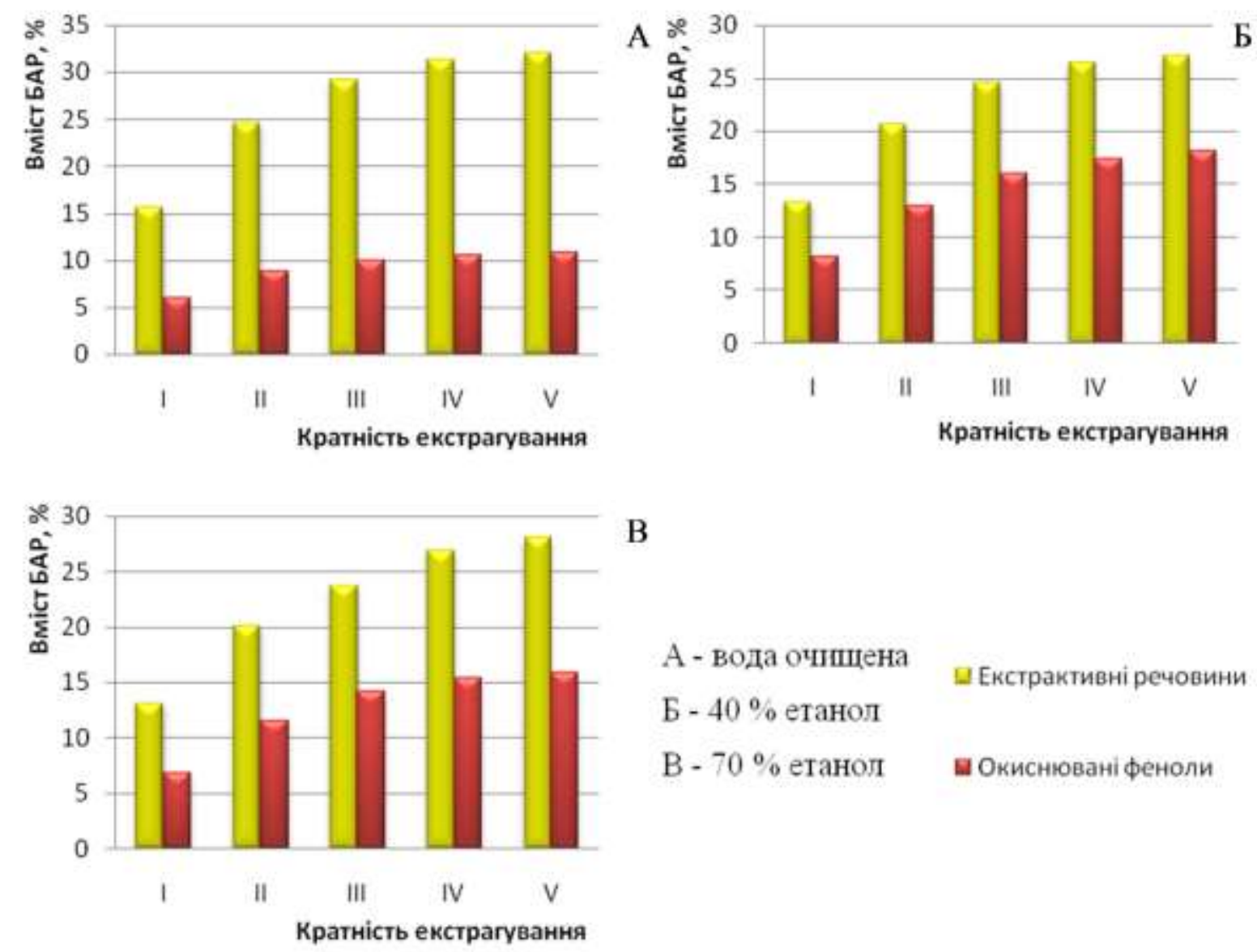

B

$$
\begin{aligned}
& \text { А - вода ошшена ш Екстрактивні речовини } \\
& \text { Б - } 40 \% \text { етанол } \\
& \text { В - } 70 \% \text { етанол Ш Окиснюваніфеноли }
\end{aligned}
$$

Рис. 5. Вплив кратності екстракцій на вихід БАР із трави приворотня зарубчастого.

На основі проведених досліджень встановлено, що для забезпечення повноти виходу екстрактивних речовин та окиснюваних фенолів необхідно проводити 3-4-кратну екстракцію трави п. зарубчастого.

Результати проведених досліджень зі встановлення оптимальних умов одержання екстрактів трави приворотня наведено в табл. 2.

Таблиця 2. Оптимальні умови екстракції БАР з трави приворотня зарубчастого.

\begin{tabular}{|c|l|c|c|c|}
\hline $\begin{array}{c}\text { Ступінь } \\
\text { подрібнення, } \\
\text { мм }\end{array}$ & Екстрагент & $\begin{array}{c}\text { Співвідно- } \\
\text { шення } \\
\text { сировина і } \\
\text { екстрагент }\end{array}$ & $\begin{array}{c}\text { Час } \\
\text { одноразової } \\
\text { екстракції, хв }\end{array}$ & $\begin{array}{c}\text { Кратність } \\
\text { екстракцій }\end{array}$ \\
\hline \multirow{3}{*}{$0,5-2,5$} & Вода очищена & $1: 15$ & 30 & $3-4$ \\
\cline { 2 - 5 } & $40 \%$ етанол & $1: 10$ & 30 & $3-4$ \\
\cline { 2 - 5 } & $70 \%$ етанол & $1: 10$ & 30 & $3-4$ \\
\hline
\end{tabular}


Результати досліджень (Табл. 2) показали, що оптимальними умовами виділення БАР була екстракція трави п. зарубчастого, подрібненої до розміру частинок $0,5-2,5$ мм водою очищеною $P, 40 \%$ етанолом $P$ та $70 \%$ етанолом $P$ на водяному нагрівнику протягом 30 хв при періодичному перемішуванні. Оптимальне співвідношення між сировиною і екстрагентом становило 1:10 1:15 в залежності від виду екстрагента. Повнота виділення БАР досягалася при 3-4-кратній екстракції.

Визначення технологічних параметрів трави п. зарубчастого та вибір оптимальних умов екстрагування стали передумовою для одержання екстрактів на його основі.

Висновки. Експериментально встановлено оптимальні технологічні параметри трави приворотня зарубчастого: втрату в масі при висушуванні, питому, об'ємну та насипну густину, пористість, порізність та вільний об'єм шару сировини. Вивчено вплив способу подрібнення, виду екстрагенту, співвідношення між сировиною і екстрагентом, часу та кратності екстракції на вихід біологічно активних речовин з досліджуваної сировини.

Конфлікт інтересів. Автори повідомляють про відсутність у них конфлікту інтересів.

\section{Література.}

1. Hlukhaniuk, T. Kuzminchuk, R. Chyzhovych et al. Research of grinding degree influence and polar solvents nature on the efficiency of oil withdrawal from vegetable raw material using extraction method. Chemistry, Technology and Application of Substances. Lviv : Lviv Politechnic Publishing House, 2020; Vol 3; 1: P. 161-168. Available from: DOI: https://doi.org/10.23939/ctas2020.01.161

2. Protunkevych O.O. Doslidzhennya tekhnolohichnykh kharakterystyk kvitok kalenduly (Flores Calendulae) dlya optymizatsiyi ekstraktsiyi flavonoyidiv // O.O. Protunkevych, K.O. Prysyazhnyuk, L.A. Ponomar'ova // Pivdennoukrayins'kyy medychnyy naukovyy zhurnal. 2019; 24; P. 56-60.

3. Gupta A. Modern extraction methods for preparation of bioactive plant extracts / A. Gupta, M. Naraniwal, V. Kothari // International J. of Applied and Natural Sciences. $\quad 2012$; Vol. $1 ; \quad 1 ; \quad$ P. 8-26. URL: https://www.researchgate.net/publication/236229645 Modern extraction methods f or_preparation_of_bioactive_plant_extracts.

4. Grytsyk L.M., Tuchak N.I., Grytsyk A.R. Application of the genus alchemilla 1. In medicine and pharmacy. Ukrayins'kyy medychnyy al'manakh, 2012; 15(2); P. 4548.

URL:

http://irbis-nbuv.gov.ua/cgi-

bin/irbis64r_81/cgiirbis_64.exe?C21COM=2\&I21DBN=UJRN\&P21DBN=UJRN\&Z21

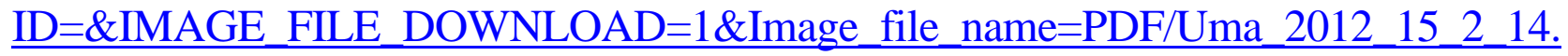
pdf

5. The State Pharmacopoeia of Ukraine: in 3 supplements / State Institution "Ukrainian Scientific Pharmacopoeial Center for Quality of Medicines". 2 ed. Kharkiv, 2015. T. 1.1128 p. 